\title{
Brucellosis and its associated risk factors to humans and domestic ruminants in Kagera Ecosystem, Tanzania
}

\author{
Jean Bosco Ntirandekura ${ }^{1,2}$, Lucas Eliaimringi Matemba ${ }^{3}$, Sharadhuli Iddi Kimera ${ }^{1}$, \\ John Bwayla Muma ${ }^{4}$, Esron Daniel Karimuribo ${ }^{1}$
}

1. Sokoine University of Agriculture, College of Veterinary Medicine and Biomedical Sciences.

2. Université du Burundi, Département de Santé et Productions Animales.

3. National Institute for Medical Research, Dodoma, Tanzania.

4. University of Zambia, School of Veterinary Medicine, Department of Disease Control, Lusaka, Zambia.

\section{Emails:}

Lucas Eliaimringi Matemba: Email: lmatemba@gmail.com; Sharadhuli Iddi Kimera Email: sikimera@gmail.com; John Bwayla Muma: Email: jmuma@unza.zm; Esron Daniel Karimuribo:

Email: ekarimu@yahoo.co.uk

\begin{abstract}
Background: Brucellosis is an important disease for both veterinary and public health. A study was conducted to understand the seroprevalence of brucellosis and its associated risk factors in pastoral areas of Kagera, Tanzania.

Methods: Sera from 156 patients with malaria-like symptoms were analyzed using the commercial rapid agglutination test (specific for B.abortus and B.melitensis detection) and Fluorescence Polarization Assay (FPA). Sera from 426 cattle, 206 goats and 197 sheep were analyzed using Rose Bengal Plate (RBPT) and Competitive ELISA (c-ELISA) tests.

Results: In humans, overall brucellosis, B. abortus, and B. melitensis sero-prevalences were 7.7\% (95\%CI: 3.8-12.2\%), 1.9\% (95\% CI: 0.4-4.5\%), and $5.8 \%$ (95\%CI: 2.6-10.6\%), respectively. At animal level, seropositivity was 5.9\% (95\%CI: 4.0-8.6\%), 2.5\% (95\%CI: $0.8-5.7 \%)$ and $0.5 \%$ (95\% CI: $0.01-2.8 \%)$ in cattle, goats and sheep, respectively. At herd level, seropositivity was $18.2 \%$ (95\% CI: $12.0-25.8 \%)$ in cattle and 6.9\% (95\%CI: 2.2-15.3\%) in small ruminants. Brucellosis was associated with assisting in parturition without wearing protective gears $(\mathrm{OR}=5.6 ; \mathrm{p}=0.02)$ in humans, herds of 50-200 animals $(\mathrm{OR}=4.2$, $\mathrm{p}=0.01)$ and cattle $(\mathrm{OR}=3.5 ; \mathrm{p}=0.01)$. The knowledge of brucellosis among pastoralists $(\mathrm{OR}=0.1 ; \mathrm{p}<0.01)$ was a protective factor.

Conclusion: Brucella infections could be occurring in pastoralists and domestic ruminants in Kagera. Community health education is necessary for the control of brucellosis in Tanzania.
\end{abstract}

Keywords: Brucellosis; pastoralists; risk factors; Tanzania.

DOI: https://dx.doi.org/10.4314/ahs.v21i2.6

Cite as: Ntirandekura JB, Matemba LE, Kimera SI, Muma JB, Karimuribo ED. Brucellosis and its associated risk factors to humans and domestic ruminants in Kagera Ecosystem, Tanzania. Afri Health Sci. 2021;21(2). 523-530. https://dx.doi. org/10.4314/abs.v21i2.6

\section{Introduction}

Brucellosis is a zoonotic disease that affects humans and animals globally. It is acquired by direct or indirect contact with infected animals or their products. In humans, the disease is under-diagnosed worldwide ${ }^{1}$ and

\section{Corresponding author: \\ Jean Bosco Ntirandekura, \\ Sokoine University of Agriculture, \\ College of Veterinary Medicine and Biomedical \\ Sciences, Department of Veterinary Medicine \\ and Public Health, Morogoro, Tanzania. \\ Phone number: +255742601303 \\ Email: bojenti2010@gmail.com}

the symptoms are often vague but may include: undulating fever (the most common symptom), body-wide aches and pains, headache, and night sweats. Domestic animals are infected through a direct contact with aborted materials, vaginal discharges, milk and semen from Brucella infected animals. Different studies on brucellosis have been carried out in East African countries. In Uganda ${ }^{2}$ and Kenya ${ }^{3}$ studies reported different prevalence levels, depending upon the locations, the methods of diagnosis used and according to species. Previous studies on brucellosis in Tanzania have demonstrated the importance of the disease as zoonosis $^{4-7}$. Other studies conducted on brucellosis in some ecosystems in Tanzania reported prevalence of this 
disease in humans, livestock and wildlife interface. For instance, anti-Brucella antibodies were detected in humans $(0.6 \%)$; in cattle $(6.8 \%)$, in goats $(1.6 \%)$ and in buffaloes $(7.9 \%)^{4}$. In addition, a $10.5 \%$ prevalence of brucellosis in trade stock of Karagwe district has been reported, which poses a risk of its transmission through trade animals ${ }^{8}$. Due to its economic importance and social impact in the population (miscarriages, infertilities and reduction of milk production), brucellosis in Kagera ecosystem calls for researchers' attention. This region is in an ecosystem that borders with three countries (Burundi, Rwanda and Uganda) where, domestic animals, wildlife and human populations are constantly interacting ${ }^{9}$. Studies on brucellosis prevalence in this shared ecosystem between bordering countries are scarce. However, such researches could underscore the understanding of the transboundary issues associated with the disease transmission and the movement of people and teir livestock within ecosystems in East African Community (EAC). Therefore, the objective of this study was to estimate the magnitude of Brucella infection and identify associated risk factors among pastoralists and their domestic ruminants in Kagera ecosystem, Tanzania.

\section{Methodology \\ Study design}

A cross-sectional study was conducted in June 2017 to identify risk factors associated with seropositivity against Brucella spp. in humans and domestic ruminants in pastoral areas of Kagera Region (two districts: Ngara and Karagwe). Eighteen villages were purposively selected from peri-urban and rural areas (Figure 1).

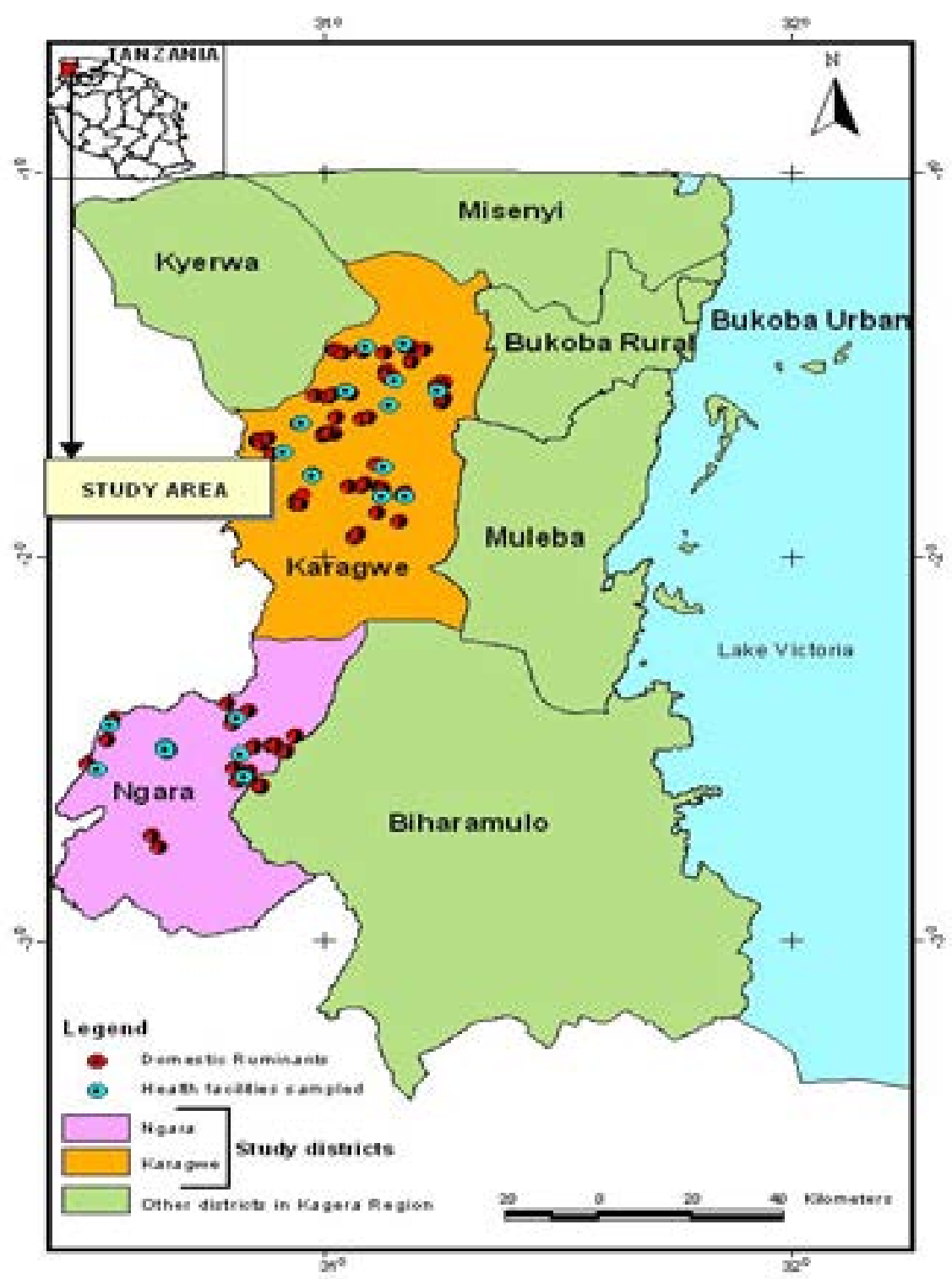

Figure 1: Map showing study districts (Karagwe and Ngara) 
Ten herds were also purposively selected in each village after considering some factors like villages located on borders with neighboring countries, herds with mixed animals, herds practicing communal grazing. Moreover, health facilities (dispensaries and health centers) located in the selected villages were included in the study for blood sampling on patients with malaria-like symptoms (fever, joint pain, headache, back pain, fatigue and nausea). In addition, two district hospitals were included for human sampling due to the big number of patients frequenting in these areas. Participants were recruited in health facilities (14 health centers and 5 hospitals) at the moment they were coming for malaria checking in the morning. Most patients that were included in the study lived in close proximity with domestic animals that were also sampled in this study area and majority of them (94\%) were animal keepers. Assisted by local phlebotomists, plain vacutainer tubes were used to collect $5 \mathrm{ml}$ of venous blood from patients. Prior to this, consent was obtained after explaining the study objectives to the participants. Using a formula: Z2* Pexp (1 -Pexp) /D2 10, sample sizes of 234 humans, 492 cows, 200 goats and 200 sheep were calculated. Herds were grouped according to the number of animals (small size: 1-50 animals; medium size: 50-200 animals and large : $>200$ animals). Domestic ruminants were randomly sampled in the selected households using plain vacutainer tubes to collect $5 \mathrm{ml}$ of venous blood assisted by local veterinary technicians. Sampling was done after getting the owner's consent. Interviews were conducted on patients and owners of animals in Kiswahili (national language). Due to the language barrier of the principal investigator, an appointed translator assisted. Structured questionnaires digitalized by AfyaData software 11 were filled using smart mobile phones to collect data on risk factors with main variables in patients (symptoms, consumption of unboiled milk, assisting parturition without wearing protective gears, living in close proximity with domestic animals, livestock keeping). In case of domestic ruminants, factors evaluated included: sharing source of water, communal grazing, sharing bulls and history of miscarriage.

\section{Laboratory analysis}

Human sera were double checked for anti-Brucella antibodies of B. abortus and B. melitensis or for cross-reactions using the commercial rapid agglutination test according to the manufacturer's instructions (ARKRAY Healthcare Pvt.ltd-INDIA, lots 15SA402-05 and 15SA403-05). Only samples with agglutinations on the slides were subjected to the confirmation using Fluorescent Polarization Assay according to the manufacturer's instructions (Ellie LLC, USA, Brucella FPA, code B1001). The cut-off was fixed at $115 \mathrm{mP}$ (millipolarization units) with a sensitivity and specificity of 99.03 and $99.9 \%$. For domestic animals, sera were screened firstly using Rose Bengal Plate test. Samples only with a reaction were then subjected to confirmation using the c-ELISA test according to manufacturers' instructions (APHA Scientific, UK. COMPELISA 160\&400). Patients (humans) reacting to Rapid slide and FPA tests were considered to be seropositive to brucellosis. Domestic ruminants were considered to be seropositive if they reacted to both RBP and c-ELISA tests.

\section{Ethical consideration}

This study was also approved by institutional review board of Sokoine University of Agriculture and the Medical Research Coordinating Committee of the $\mathrm{Na}$ tional Institute for Medical Research (ref: NIMR/HQ/ R.8a/Vol.IX/2456).

\section{Data analysis}

Questionnaires were uploaded in excel sheet for analysis. Seroprevalence in humans and domestic ruminants were determined based on criteria of seropositivity for an individual during laboratory analysis. The overall seroprevalence were determined for each species and the herd seroprevalence was also computed. All independent variables were screened by univariable logistic regression analysis for their association with the positivity of brucellosis in Kagera using IBM ${ }^{\circledR}$ SPSS ${ }^{\circledR}$ Statistics 21. Variables with p-value less than 0.2 (univariable logistic regression) were included in the risk factors assessment by a multivariable logistic regression model, reporting odds ratio with $95 \%$ confidence intervals. A P-value less than 0.05 was considered as significant.

\section{Results \\ Demographic characteristics of humans and rumi- nants sampled in Kagera Region}

A total of 192 herds were visited and 156, 426, 206 and 197 sera were sampled from humans, cattle, goats and sheep, respectively. Patients were aged between 5 and 77 years (mean $=35 \pm 16.6$ ) with a total of 55 males and 101 females (sex ratio of 1:2) in the two districts. Livestock owners were between 24 and 84 years of age (mean = $47.5 \pm 11.7$ ), and the age of animals sampled was between 18 months and 8 years for cattle, and 8 months to 5 years for small ruminants. 
Seroprevalence of brucellosis in humans and domestic ruminants in Kagera Region

In humans, from FPA test, the overall brucellosis $(\mathrm{n}=12), B$. abortus $(\mathrm{n}=3)$, and B. melitensis $(\mathrm{n}=9)$ sero-prevalences were 7.7\% (95\%CI: $4.04-13.05 \%$ ), 1.9\% (95\%CI: $0.4-4.5 \%$ ), and $5.8 \%$ (95\% CI: 2.6-10.6\%), respectively. No sample was positive to both $B$. meltensis and B. abortus. The overall seroprevalence of brucellosis in domestic ruminants (from c-Elisa test) was 3.7\% (95\% CI: 4 -8.6) while the herd prevalence was 13.5\% (95\% CI: $9-19.2 \%$ ). At herd level, the prevalence of brucellosis was 18.2\% (95\% CI: $12-25.8 \%$ ) and $6.8 \%$ $(95 \% \mathrm{CI}=2.2-15.3 \%)$ in cattle and small ruminants, respectively.

\section{Logistic regressions}

The univariable logistic regression was done to assess the association between each variable and the seropositivity of brucellosis in Kagera region (Table1 \& Table2). The final model for the risk factors associated to Brucella infections in humans and domestic ruminants are presented in Table 3.

Table 1: Univariable logistic regression between positivity of brucellosis and different variables in humans in Kagera Region.

\begin{tabular}{|c|c|c|c|c|}
\hline Variable & Extent & $\mathbf{N}$ & $\begin{array}{l}\text { Positive to } \\
\text { FPA test (\%) }\end{array}$ & $\begin{array}{l}\text { p- } \\
\text { value } \\
\end{array}$ \\
\hline \multirow[t]{2}{*}{ District } & Ngara & 53 & $5(9.4)$ & 0.56 \\
\hline & Karagwe & 103 & $7(6.8)$ & \\
\hline \multirow[t]{2}{*}{ Health facilities } & Local dispensaries & 113 & $9(7.9)$ & 0.8 \\
\hline & District hospitals & 46 & $3(6.9)$ & \\
\hline \multirow[t]{2}{*}{ Sex } & Female & 97 & $8(8.2)$ & 0.98 \\
\hline & Male & 59 & $4(6.8)$ & \\
\hline \multirow[t]{3}{*}{ Age } & 5-30 years & 74 & $5(6.7)$ & 0.6 \\
\hline & $31-60$ years & 62 & $5(8)$ & \\
\hline & $>60$ years & 20 & $2(10)$ & \\
\hline \multirow[t]{4}{*}{ Marital status } & Single & 36 & $1(2.8)$ & 0.6 \\
\hline & Married & 110 & $11(10)$ & \\
\hline & Divorced & 4 & $0(0)$ & \\
\hline & Widower & 6 & $0(0)$ & \\
\hline \multirow[t]{2}{*}{ Fever } & Yes & 133 & $10(7.5)$ & 0.8 \\
\hline & No & 23 & $2(8.7)$ & \\
\hline \multirow[t]{2}{*}{ Back pain } & Yes & 62 & $3(4.8)$ & 0.4 \\
\hline & No & 94 & $9(9.6)$ & \\
\hline \multirow[t]{2}{*}{ Joint pain } & Yes & 40 & $4(10)$ & 0.7 \\
\hline & No & 116 & $8(7)$ & \\
\hline \multirow{2}{*}{$\begin{array}{l}\text { History of miscarriage } \\
\text { (women) }\end{array}$} & Yes & 5 & $1(20)$ & 0.3 \\
\hline & No & 151 & $11(7.3)$ & \\
\hline \multirow[t]{2}{*}{ Dinking unboiled milk } & Yes & 70 & $8(11.4)$ & 0.2 \\
\hline & No & 86 & $4(4.7)$ & \\
\hline \multirow[t]{2}{*}{ Consuming cheese } & Yes & 33 & $4(12.1)$ & 0.47 \\
\hline & No & 123 & $8(6.5)$ & \\
\hline \multirow{2}{*}{$\begin{array}{l}\text { Living with domestic } \\
\text { animals }\end{array}$} & Yes & 120 & $9(7.5)$ & 0.84 \\
\hline & No & 36 & $3(8.3)$ & \\
\hline \multirow{2}{*}{$\begin{array}{l}\text { Assisting parturition } \\
\text { without protective gears }\end{array}$} & Yes & 19 & $4(21.1)$ & 0.06 \\
\hline & No & 137 & $8(5.8)$ & \\
\hline \multirow{2}{*}{$\begin{array}{l}\text { History of } \\
\text { miscarriage (herd) }\end{array}$} & Yes & 116 & $9(7.8)$ & 0.7 \\
\hline & No & 40 & $3(7.5)$ & \\
\hline \multirow{2}{*}{$\begin{array}{l}\text { Poor disposal of aborted } \\
\text { materials in herds }\end{array}$} & Yes & 78 & $9(11.5)$ & 0.1 \\
\hline & No & 78 & $3(3.8)$ & \\
\hline \multirow{2}{*}{$\begin{array}{l}\text { Permanent contact with } \\
\text { livestock }\end{array}$} & Yes & 148 & $11(7.4)$ & 0.87 \\
\hline & No & 8 & $1(12.5)$ & \\
\hline
\end{tabular}


Table 2: Univariable Logistic regression of risk factors and the seroprevalence of brucellosis in domestic ruminants (animal level) in Kagera Region

\begin{tabular}{|c|c|c|c|c|}
\hline Variable & Extent & $\mathbf{N}$ & $\begin{array}{l}\text { Positive to c- } \\
\text { Elisa test (\%) }\end{array}$ & $\begin{array}{l}\mathrm{p}- \\
\text { value }\end{array}$ \\
\hline \multirow[t]{2}{*}{ District } & Karagwe & 580 & $27(4.7)$ & 0.05 \\
\hline & Ngara & 249 & $4(1.6)$ & \\
\hline \multirow[t]{2}{*}{ Species } & Cattle & 403 & $6(1.5)$ & $<0.01$ \\
\hline & $\begin{array}{l}\text { Caprine and } \\
\text { ovine }\end{array}$ & 426 & $25(5.9)$ & \\
\hline \multirow[t]{3}{*}{ Herd management } & Pastoralism & 735 & $30(4.1)$ & 0.2 \\
\hline & Zero grazing & 50 & $0(0)$ & \\
\hline & Mixing & 44 & $1(2.3)$ & \\
\hline \multirow[t]{2}{*}{ Herd size } & $\begin{array}{l}\text { Medium (50- } \\
200)\end{array}$ & 500 & $26(5.2)$ & 0.02 \\
\hline & Small $(<50)$ & 329 & $5(1.6)$ & \\
\hline \multirow[t]{2}{*}{ Herd location } & Rural & 747 & $29(3.9)$ & 0.72 \\
\hline & Peri-urban & 82 & $2(2.4)$ & \\
\hline \multirow[t]{2}{*}{ Communal grazing } & Yes & 169 & $9(5.3)$ & 0.32 \\
\hline & No & 660 & $22(3.3)$ & \\
\hline \multirow{2}{*}{$\begin{array}{l}\text { Sharing pasture } \\
\text { with wildlife }\end{array}$} & Yes & 247 & $13(5.3)$ & 0.19 \\
\hline & No & 582 & $18(3.1)$ & \\
\hline \multirow{2}{*}{$\begin{array}{l}\text { Sharing water } \\
\text { sources among } \\
\text { herds }\end{array}$} & Yes & 573 & $23(4.0)$ & 0.67 \\
\hline & No & 256 & $8(3.1)$ & \\
\hline \multirow{2}{*}{$\begin{array}{l}\text { Sharing bulls } \\
\text { among herds }\end{array}$} & Yes & 237 & $5(2.1)$ & 0.12 \\
\hline & No & 592 & $26(4.4)$ & \\
\hline \multirow{2}{*}{$\begin{array}{l}\text { History of } \\
\text { miscarriage (in } \\
\text { herds) }\end{array}$} & Yes & 601 & $26(4.3)$ & 0.21 \\
\hline & No & 228 & $5(2.2)$ & \\
\hline \multirow{2}{*}{$\begin{array}{l}\text { Knowledge on } \\
\text { brucellosis among } \\
\text { pastoralists }\end{array}$} & Yes & 367 & $3(0.82)$ & $<0.01$ \\
\hline & No & 462 & $28(6.06)$ & \\
\hline \multirow{2}{*}{$\begin{array}{l}\text { Vaccination of } \\
\text { diseases (in herds) }\end{array}$} & Yes & 602 & $28(4.7)$ & 0.04 \\
\hline & No & 227 & $3(1.3)$ & \\
\hline \multirow{2}{*}{$\begin{array}{l}\text { Vaccination of } \\
\text { brucellosis (in } \\
\text { herds) }\end{array}$} & Yes & 62 & $1(1.6)$ & 0.4 \\
\hline & No & 767 & $30(3.9)$ & \\
\hline
\end{tabular}


Table 3: Multivariable logistic regression of risk factors of brucellosis positivity in humans and domestic ruminants in Kagera.

\begin{tabular}{|c|c|c|c|c|}
\hline Variables & Extent & OR & $95 \%$ IC & p-value \\
\hline \multicolumn{5}{|c|}{ Risk factors in humans } \\
\hline \multirow[t]{2}{*}{ Drinking unboiled milk } & Yes & 3.2 & $0.8-12.4$ & 0.09 \\
\hline & No & Ref & & \\
\hline \multirow{2}{*}{$\begin{array}{l}\text { Assisting in parturition } \\
\text { without protective gears }\end{array}$} & Yes & 5.6 & $1.3-23.5$ & 0.02 \\
\hline & No & Ref & & \\
\hline \multicolumn{5}{|c|}{ Risk factors in domestic ruminants (herd level) } \\
\hline \multirow[t]{2}{*}{ Species } & Bovine & 3.5 & $1.3-9.8$ & 0.01 \\
\hline & $\begin{array}{l}\text { Caprine and } \\
\text { ovine }\end{array}$ & Ref & & \\
\hline \multirow[t]{2}{*}{ Herd size } & Small $(<50)$ & Ref & & \\
\hline & $\begin{array}{l}\text { Medium } \\
(50-200)\end{array}$ & 4.2 & $1.4-12.7$ & 0.01 \\
\hline \multirow{2}{*}{$\begin{array}{l}\text { Knowledge on } \\
\text { brucellosis among } \\
\text { pastoralists }\end{array}$} & Yes & 0.1 & $0.02-0.5$ & $<0.01$ \\
\hline & No & Ref & & \\
\hline
\end{tabular}

\section{Discussion}

Brucellosis is a zoonotic disease of concern for both veterinary and public health in Tanzania ${ }^{12-14}$. In this study, a rapid agglutination test detected B. melitensis and $B$. abortus antibodies which were confirmed by the FPA test in patients with malaria-like symptoms. Our results are closer to those reported in a study conducted in Moshi, Northern Tanzania ${ }^{5}$, but there are lower compared to reports from Sengerema district ${ }^{15}$ and Mwanza Region ${ }^{16}$. Nevertheless, there was no difference regarding positivity to brucellosis among febrile and non-febrile participants (Table 1). This may be due to the small number of persons who were seropositive to brucellosis in this group. In Mikumi ecosystem, the assessment of brucellosis prevalence in febrile group revealed higher positivity of $23.9 \%$ than in non-febrile group $3.7 \%{ }^{17}$. In addition, there was no difference of Brucella positivity between women with history of miscarriage and those witout such experience (Table 1). This could be associated to the low number of pregnant women in our sample. Although some studies have demonstrated the interactions between brucellosis and the animal trophoblast, the pathogenesis of miscarriage in women remains very unclear ${ }^{18}$. In other report in Tanzania, no prevalence of brucellosis was found in humans in agro-pastoral communities of Serengeti district ${ }^{7}$. Elsewhere, seropositivity of brucellosis in humans were also reported in Uganda $(17 \%)^{19}$; in Kenya $(2.2-14.1 \%)^{20}$ and in Ethiopia (3-34.9\%) ${ }^{21}$. Assisting parturitions without wearing protective gears (Table3) increased the risk of exposure to Brucella infections in humans in Kagera. Similar results were reported in northern part of Tanzania ${ }^{5}$. In addition, the habit of drinking unboiled milk (Table 3) seemed to be a risk factor of for human infections even if it was less significantly associated with brucellosis seropositivity in Kagera. Furthermore, there is a report on habit to drink unboiled milk by people from the study area ${ }^{22}$.

The prevalence of brucellosis has previously been detected in trade stock at $10.5 \%{ }^{8}$. Our results are similar to those reported in indigenous cattle (animal level 5.6\% and herd level $21.7 \%$ ) in western part of Tanzania ${ }^{23}$ and closer to those reported in Lushoto and Rungwe districts ${ }^{24}$ in small dairy cattle. In addition, the prevalence of brucellosis was $11.3 \%$ in indigenous cattle in Mbeya Region ${ }^{25}$. Other studies reported prevalence of brucellosis in cattle ${ }^{4,26}$ in pastoral areas of Tanzania. In this study, the prevalence of bovine brucellosis at herd level was within the range (16.2\%, 95\% CI: $10.2-25.7 \%)$ reported in sub-Saharan Africa ${ }^{27}$. In this study, cattle seemed to be more at risk of getting Brucella infections compared to small ruminants (Table 3). This could be due to the abundance of this species in this pastoralist area, but also to the susceptibility of cattle to different Brucella species which can be originated from infected domestic or wild animals commingled in the study area. Also, the herds with increased number of animals (50200) were at risk to acquire Brucella infection (Table 3). Similar results were reported in Mbeya Region ${ }^{25}$ also in other parts of Africa ${ }^{28,29}$. In fact, animals in large herds of cattle are condemned to long mobility and migration for pasture and water sources which increase the risk of intermingling between domestic ruminants and favor the Brucella infection in pastoral areas ${ }^{3}$. However, bovine brucellosis is persistent in livestock with low level 
and relative stability of transmission in pastoral areas ${ }^{30}$. In this study, the knowledge of brucellosis among pastoralists (Table 3) was a protective factor for the disease in domestic ruminants. Nevertheless, vaccination against diseases in the herds in general was not significant in the final logistic model. These results indicated that the knowledge of the disease among pastoralists should be complimented with the vaccination program and practices of good hygiene for controlling brucellosis in their herds as reported before in the study area ${ }^{22}$.

\section{Study limitations}

Due to financial limitations, this study couldn't extend the human sample size to the community in non-fever group which could have generated additional information for the understanding of seroprevalence of brucellosis in the study area. However, sampled patients lived in close proximity with domestic animals that were also sampled in this study and majority of them (94\%) were animal keepers. The financial and time limitations influenced much the purposive sampling in this study which affects the generalizability of our results. Nevertheless, this contributed to understand the consistent of known animal husbandry and movement risk factors in the study area.

\section{Conclusion}

The seropositivity of brucellosis is distributed according to susceptible species (humans, cattle, goat and sheep) located in pastoral area of Kagera. The identified main risk factors in humans for the persistence of brucellosis in Kagera were assisting in animal parturition without wearing protective gears while in domestic ruminants, herd size and cattle increased the risk of Brucella infection. However, the knowledge of brucellosis among pastoralists seemed to be a protective factor for this zoonotic disease. Further studies with advanced diagnostic methods (culture and molecular characterization) are suggested to assess this important zoonotic disease in Kagera Region. These results are proposed for use in understanding of brucellosis in Tanzania also for the implementation of control and surveillance of this disease in East Africa.

\section{Conflict of interest disclosure}

I, Jean-Bosco Ntirandekura, declare in name of all contributors to this paper that there's no conflict of interest.

\section{References}

1. Corbel MJ. Brucellosis: an overview. Emerg. Infect. Dis. 3, 213-21 (1997).
2. Bernard F, Vincent C, Matthieu L, David R, James D. Tuberculosis and brucellosis prevalence survey on dairy cattle in Mbarara milk basin (Uganda). Prev. Vet. Med. 67, 267-281 (2005).

3. Kadohira M, McDermott JJ, Shoukri MM, Kyule $\mathrm{MN}$. Variations in the prevalence of antibody to brucella infection in cattle by farm, area and district in Kenya. Epidemiol. Infect. 118, 35-41 (1997).

4. Assenga JA, Matemba LE, Muller SK, Malakalinga JJ, Kazwala RR. Epidemiology of Brucella infection in the human, livestock and wildlife interface in the Katavi-Rukwa ecosystem, Tanzania. BMC Vet. Res. 11, 189 (2015).

5. Cash-Goldwasser S. et al. Risk Factors for Human Brucellosis in Northern Tanzania. Am. J. Trop. Med. Hyg. 98, 598-606 (2018).

6. Kunda J, Fitzpatrick J, Kazwala R, French NP, Shirima G, MacMillan A, Kambarage D, Bronsvoort M, Cleaveland S. Health-seeking behaviour of human brucellosis cases in rural Tanzania. BMC Public Health 7, 315 (2007). 7. Shirima GM, Kunda JS. Prevalence of brucellosis in the human, livestock and wildlife interface areas of Serengeti National Park, Tanzania. Onderstepoort J Vet Res 83, 4-pages (2016).

8. Kiputa VP, Kimera SI, Wambura PN. Studies on the role of trade cattle in the transmission of brucellosis in Karagwe district, Tanzania. Tanzania Vet. J. 25, 48-59 (2008).

9. United Republic of Tanzania. Kagera Regional Investment Profile. (2013).

10. Martin SW, Meek AH, Willeberg P. Veterinary epidemiology. Principles and methods. Vet. Epidemiol. Princ. methods. (1987).

11. Karimuribo ED. et al. A Smartphone App (AfyaData) for Innovative One Health Disease Surveillance from Community to National Levels in Africa: Intervention in Disease Surveillance. JMIR Public Heal. Surveill. 3, e94 (2017).

12. Assenga JA, Matemba LE, Malakalinga JJ, Muller SK, Kazwala, RR. Quantitative analysis of risk factors associated with brucellosis in livestock in the Katavi-Rukwa ecosystem, Tanzania. Trop. Anim. Health Prod. 48, 303-309 (2016).

13. Kunda $\mathrm{J}$ et al. Brucellosis in Arusha and Manyara regions, Tanzania: a challenge to public health. Tanzania Med. J. 20, 1-4 (2005).

14. Swai ES, Schoonman L. Human brucellosis: seroprevalence and risk factors related to high risk occupational groups in Tanga Municipality, Tanzania. Zoonoses Public Health 56, 183-187 (2009).

15. Mngumi EB, Mirambo MM, Wilson S, Mshana SE. Predictors of specific anti-Brucella antibodies among 
humans in agro-pastoral communities in Sengerema district, Mwanza, Tanzania: the need for public awareness. Trop. Med. Health 44, 34 (2016).

16. Mirambo MM. et al. Seropositivity of Brucella spp. and Leptospira spp. antibodies among abattoir workers and meat vendors in the city of Mwanza, Tanzania: A call for one health approach control strategies. PLoS Negl. Trop. Dis. 12, e0006600 (2018).

17. James LW. Studies on human brucellosis in the Mikumi selous ecosystem, Morogoro, Tanzania. (MSc. Dissertation. Sokoine University of Agriculture, 2013). 18. Kurdoglu M, Cetin O, Kurdoglu Z, Akdeniz H. The Effect of Brucellosis on Women's Health and Reproduction. Int. J. Women's Heal. Reprod. Sci. 3, 176-183 (2015).

19. Tumwine G, Matovu E, Kabasa JD, Owiny DO, Majalija S. Human brucellosis: sero-prevalence and associated risk factors in agro-pastoral communities of Kiboga District, Central Uganda. BMC Public Health 15, 900 (2015).

20. Ogola E et al. Sero-prevalence of Brucellosis in Humans and their Animals: A Linked Cross-sectional Study in Two Selected Counties in Kenya. Online J. Public Health Inform. 6, (2014).

21. Genene R, Desalew M, Yamuah L, Hiwot T, Teshome G, Asfawesen G, Abraham A, Abdoel TH, Smits HL. Human brucellosis in traditional pastoral communities in Ethiopia. Int. J. Trop. Med. 4, 59-64 (2009).

22. Ntirandekura JB, Matemba LE, Ngowi HA, Kimera

SI, Karimuribo ED. Knowledge, perceptions and practices regarding brucellosis in pastoral communities of Kagera Region, Tanzania. J. Adv. Vet. Anim. Res. 5, 343 (2018).
23. Chitupila GY, EVGK, NJM-M. Epidemiological study of bovine brucellosis in indigenous cattle population in Kibondo and Kakonko Districts, Western Tanzania. Livest. Res. Rural Dev. 27, 1-3 (2015).

24. Mfune R. Epidemiological study of bovine brucellosis in smallholder dairy cattle in Lushoto and Rungwe districts, Tanzania. (MSc. Dissertation. Sokoine University of Agriculture, 2015).

25. Sagamiko FD. et al. Sero-prevalence of Bovine Brucellosis and associated risk factors in mbeya region, Southern highlands of Tanzania. Acta Trop. 178, 169 175 (2018).

26. Karimuribo ED, Ngowi HA, Swai ES, Kambarage DM. Prevalence of brucellosis in crossbred and indigenous cattle in Tanzania. Livest. Res. Rural Dev. 19, 148152 (2007).

27. Mangen MJ, Otte J, Pfeiffer D, Chilonda P. Bovine brucellosis in sub-Saharan Africa: estimation of sero-prevalence and impact on meat and milk offtake potential. Food Agric. Organ. United nations, Rome (2002).

28. Awah-Ndukum J et al. Seroprevalence and Associated Risk Factors of Brucellosis among Indigenous Cattle in the Adamawa and North Regions of Cameroon. Vet. Med. Int. 2018, 1-10 (2018).

29. Megersa B et al. Cattle brucellosis in traditional livestock husbandry practice in Southern and Eastern Ethiopia, and its zoonotic implication. Acta Vet. Scand. 53, 24 (2011).

30. Racloz V, Schelling E, Chitnis N, Roth F, Zinsstag J. Persistence of brucellosis in pastoral systems. Rev. Sci. Tech. 32, 61-70 (2013). 